\title{
Modern Methods of Grassland Management in Feeding the Dairy Herd
}

\author{
By W. Holmes, Hannah Dairy Research Institute, Kirkhill, Ayr
}

In the past Io years grassland has assumed a more important role in dairy farming than at any time in the past century. The shortage and high cost of animal feedingstuffs during the war coincided with and stimulated the development and acceptance of improved methods of growing and using grass. It now appears possible that by the full adoption of these methods, output per acre-a factor of critical importance in British agriculture-can be doubled.

\section{Efficient utilization of grass}

The guiding principle in efficient utilization is to allow the grass to grow until it reaches the leafy or long leafy stage, then to defoliate it rapidly and efficiently, and rest it again for the next growth. Such a system encourages the maximum production of herbage of good feeding value and maintains the root system of the grass sward in healthy condition.

Grazing methods. In summer this result can be obtained by the practice of rotational grazing in which several paddocks are successively grazed, each for only a few days, and then rested. Rotational grazing may give 10-40\% more per acre than continuous grazing. In some circumstances this improvement may scarcely justify the increased cost of fencing and water supplies, but the rotational method must be regarded as the first step to more intensive grazing. Strip or rationed grazing, which is probably the best intensive method, has been made possible by the development of the easily movable electric fence. With this cows can be offered a small area of fresh grass once or even twice a day and almost complete utilization of the pasture is effected because spoilage from treading and dung is much reduced. Strip grazing may raise production per acre by $20-35 \%$ above rotational grazing without affecting yield per cow (Procter, Hood, Ferguson \& Lewis, 1950; Holmes, Waite, Fergusson \& Campbell, 1950; Holmes, Waite, Fergusson \& MacLusky, 1952).

Grass for winter feed. In winter the modern role of grass is to provide highquality bulk feeds that can reduce, to a considerable extent, the farmer's dependence on grains, pulses and oilcakes. Grass can be stored for winter as hay, artificially dried grass or silage. But hay, by its very nature cannot be made from short leafy grass so that although it is a most useful food, which few farmers would do without, it does not provide the best means of conserving high-quality feed. Dried grass and silage can and ought to be made from grass at the leafy or long leafy stage. If artificial drying is practised four to five cuts of herbage should be taken; the yield per acre can be raised to a high level with good management, and since the losses in the drying process are small $(5-10 \%)$ the amount of food saved per acre 
is very high (see Table 2). Silage is generally made from fewer cuts of grass, and the grass is generally at a longer stage of growth. Thus the total weight of dry matter cut may be as high as with grass drying but the quality of herbage is generally somewhat lower. Moreover there are losses due to respiration and, on occasion, protein breakdown, so that the silage may yield only $60-80 \%$ of the food value of the crop cut (Watson, I939; Dodsworth \& Campbell, 1952).

\section{Increasing production of grass}

Provided good use can be made of the grass it is justifiable to increase its yield per acre. Good management methods can themselves effect a considerable increase, but the encouragement of high fertility through the leguminous plant or by the use of fertilizers can further raise production to unheard of levels. The minerals, potash and phosphate, are essential for high production. Provided they are present, nitrogen either from clover or from fertilizer can effect considerable increases in yield. Some examples from experimental plots at the Hannah Dairy Research Institute are shown in Table $\mathbf{I}$.

Table $\mathrm{I}$. The effect of clover and fertilizer nitrogen in raising production per acre where the grass is cut four to five times a year and dried

$\begin{array}{lc}\begin{array}{c}\text { Annual fertilizer } \\ \text { treatment* }\end{array} & \begin{array}{c}\text { Yield as dried } \\ \text { grass } \\ \text { (cwt./acre) }\end{array} \\ \begin{array}{l}\text { No nitrogen, medium clover } \\ \text { No nitrogen, high clover }\end{array} & 47 \\ \text { Nitrogen 260 lb./acre in five } & 58 \\ \quad \text { dressings } & \\ \text { Nitrogen 520 lb./acre in five } \\ \text { dressings }\end{array}$

Starch equivalent
(cwt./acre)
26
32
44
53

Average protein content

$(\%)$

$13 \cdot 3$

$17 \cdot 0$

$15 \cdot 7$

$18 \cdot 6$

*Applications of about $60 \mathrm{lb} . \mathrm{K}_{2} \mathrm{O}$ and $20 \mathrm{lb} . \mathrm{P}_{2} \mathrm{O}_{5}$ per ton of dried grass are also required.

Another method of increasing, and cheapening, production is to extend the grazing season by the use of grasses or management methods that produce grass in early spring and late autumn. Climatic or soil conditions, preclude, of course, the extension of the grazing season in some situations.

\section{The relative yields of grassland and other crops}

The figures given have shown that the production from grassland can be greatly increased, but this must be compared with the yields and possible increases from other crops. Table 2 shows some farm-scale results obtained on the Institute's farm. During the period $1940-9$ the yield of starch equivalent (S.E.) from grass was comparable with that from cereals, better than from beans and slightly poorer than from root crops. By better management methods the level of yield of grass had been raised some $65 \%$ by 1952 , but although an attempt was also made to raise yields of oats and beans it was less successful. Root crops were excluded in 1952 because of their heavy labour requirements in May and June when grass demands 
Table 2. Yields of starch equivalent from crops and grass obtained in farm-scale experiments at Kirkhill

$\quad$ Crop
Oats (including straw)
Beans
Swede turnips
Kale and cabbage
Grazing (full utilization)
Dried grass

Mean for $1940-9$
(cwt./acre)
$21 \cdot 6$
$13 \cdot 2$
$25 \cdot 2$
$23 \cdot 9$
$19 \cdot 3$
$21 \cdot 2$

$\begin{array}{cc}\begin{array}{c}\text { 1952 } \\ \text { (cwt./acre) }\end{array} & \begin{array}{c}\text { Increase } \\ (\%) \\ 23.8\end{array} \\ \text { I3.0 } & \text { II } \\ - & - \\ - & - \\ 31.4 & 63 \\ 35 & 65\end{array}$

the most attention, but some grain and pulse crops were retained because they do not clash in labour demand with grass and provide useful supplements to feed with grass products in winter.

\section{The place of grassland produce in the diet of the dairy cow}

A change in outlook on the feeding of dairy cattle is necessary if grassland is to play its full part. Milk yields of $50-60$ and even $70 \mathrm{lb}$./day can be obtained from cows on good grazing (Holmes, I953; Williams, 1953). Several experiments at the Hannah Institute have shown that, provided the quality of grazing was good, only very small gains in milk production were obtained when concentrates were fed in addition. Nevertheless, it is still quite common practice for dairy herds to receive liberal and often unnecessary allowances of dairy cakes during the summer months.

In winter feeding best quality dried grass can be substituted for some of the concentrated feeds commonly used, but a more practicable approach is to replace the bulky, so called, maintenance ration with less bulky and more nutritious grass products, grass silage or long dried grass in particular, in sufficient quantity to replace both the more bulky feeds and the first $4-6 \mathrm{lb}$. of the concentrate feeds. An experiment showing the success of this method has been described by Cooper (1952). Some farmers have fed cows in winter entirely on such grass feeds without any concentrates with good results. It is safer, however, to supplement them with some concentrates although less are needed and they can be of lower protein content because of the surplus protein supplied by good grass. Suitable rations have been suggested recently by the author (Holnes, 1953).

\section{Integration of the intensive methods into a farming system}

The foregoing results are sufficient to show that (I) the utilization of grassland can be made more efficient by the application of the principle of alternate rest and defoliation, (2) the output per acre of grassland produce can be increased by better management to a greater extent than with most other crops, and (3) with modified feeding practices grassland can contribute much more to the total diet of the cow than is customary. It is of particular interest, however, to consider what the effect of these various practices can be on the farm as a whole.

Results from a typical selection of west of Scotland dairy farms in 195 I, from the Hannah Institute's farm of Kirkhill in $194^{8}$, $195^{\circ}$ and $195^{2}$ and from a very 
intensively run grassland farm in Northern Ireland in $195^{2}$ are shown in Table 3 . The effect of increasing efficiency of grassland management at Kirkhill can be seen in the rise of stock-carrying capacity and production per acre from 1948 to $195^{2}$,

Table 3. Comparison of milk production per acre on farms under different systems

\begin{tabular}{|c|c|c|c|c|c|}
\hline & & $a g e$ & & & \\
\hline & $\begin{array}{c}\text { Mean for } \\
\text { sixty-three } \\
\text { west of Scotland } \\
\text { dairy farms* } \\
\text { I95 I }\end{array}$ & 1948 & $\begin{array}{c}\text { Kirkhill farm } \\
\text { I95० }\end{array}$ & $195^{2}$ & $\begin{array}{c}\text { The Wood } \\
\text { farm, Ulster } \\
\text { I952 }\end{array}$ \\
\hline Acres per cow & $3 \cdot 5$ & $3 \cdot 0$ & $2 \cdot 5$ & $2 \cdot 4$ & $2 \cdot 0$ \\
\hline Gal./acre & 181 & $2 I I$ & 241 & 299 & 355 \\
\hline Feed purchased/acre & $6 \mathrm{cwt}$. & - & - & $3 \mathrm{cwt}$. & - \\
\hline $\begin{array}{l}\text { Net gal./acre (deductions } \\
\text { based on proportion } \\
\text { of S.E. supplied by }\end{array}$ & & & & & \\
\hline bought feed) & I 5 & 2 I I & $24 \mathrm{I}$ & 276 & 355 \\
\hline Gal./cow & $640+$ & 625 & 617 & 716 & 710 \\
\hline
\end{tabular}

* Hunt (1953).

+ Sales per cow: 40-60 gal. should be added for amount of milk fed to calves.

and the effectiveness of full commercial exploitation of grass uncomplicated by experimental considerations is very well shown by the farm in Ulster, where productivity per acre was more than double that of the average dairy farm.

Although the figures presented show that vast increases in output per acre are possible, it should be appreciated that there are many obstacles to overcome before the new grassland practices are widespread. Of these obstacles, tradition, suspicion and lack of sufficient financial incentive are probably the most important.

The author is indebted to Mr J. O'Neill, 'The Wood, Lurgan, Co. Armagh, for permission to quote the figures included in the last column of Table 3 .

\section{REFERENCES}

Cooper, M. M. (1952). Agric. Progr. 27, 3 I.

Dodsworth, T. L. \& Campbell, W. H. McK. (1952). F. Brit. Grassl. Soc. 7, I 5 I

Holmes, W. (1953). Adv. Leafl. Dep. Agric. Scot., N.S. no. 25.

Holmes, W., Waite, R., Fergusson, D. L. \& Campbell, J. I. (1950). F. agric. Sci. 40, 38 I

Holmes, W., Waite, R., Fergusson, D. L. \& MacLusky, D. S. (1952). F. agric. Sci. 42, 304.

Hunt, A. F. (r953). Rep. W. Scot. agric. Coll. Econ. Dep. no. Io.

Procter, J., Hood, A. E. M., Ferguson, W. S. \& Lewis, A. H. (1950). F. Brit. Grassl. Soc. 5, 243.

Watson, S. J. (1939). The Science and Practice of Conservation: Grass and Forage Crops. London: Fertilizers and Feeding Stuffs Journal.

Williams, G. (1953). Yearb. Green Crop Dry. Res, Ass. p. 100. 